Vyshnevska 0., Doctor of Economics, Professor, Dean of Accounting and Finance Faculty, Mykolayiv National Agrarian University, Mykolayiv, Ukraine

ORCID ID: 0000-0003-1996-4590

e-mail: vishnevskaya@mnau.edu.ua

Bobrovska N., Candidate of Economic Sciences, Senior Lecturer of the Department of Accounting and Taxation, Mykolayiv National Agrarian University, Mykolayiv, Ukraine

ORCID ID: 0000-0001-9178-0425

e-mail: bobrovskanadia@gmail.com

\title{
The national wealth of the state: ecological and economic criteria
}

Abstract. Introduction. An important feature of wealth is the use of economic resources necessary for organization and support of human existence. Thus, the study of structural changes in the national wealth of the country becomes urgent because of the need to introduce priority directions of preservation of the resource base, ensuring the efficiency of use, which will promote the growth of macroeconomic stability.

Purpose. The purpose of the study is to substantiate the essence of the concept of "the national wealth", generalization of processes and phenomena that have an impact on the macroeconomic stability of the state, taking into account the national wealth, its quantitative composition and qualitative content. Particularly relevant issue is the growing need to level the negative impact of globalization factors on the socio-economic development of the world states, the preservation of ecosystems.

Results. The article substantiates the essence of the concept of "the national wealth" and generalizes the processes and phenomena that have an impact on the macroeconomic growth of the state, taking into account national wealth, its quantitative composition and qualitative content.

It was investigated that the national wealth of the state is a set of components that provide opportunities for the development of the branches of the economy and the social sphere, support and guarantee national interests in view of the need to form a security environment, preserve the territorial integrity and mentality, the cultural heritage of the nation. The urgency of introducing measures to preserve the national wealth of the state is confirmed by the influence of globalization factors, the need to increase the competitive position in the global market.

Conclusion. It is stipulated that state policy should be aimed at systematic implementation of the complex of actions that guarantee the national interests, preserve, increase the national wealth, and provide a safe economic and ecological space. The practical implementation of measures is to comply with social and ecological responsibility, fulfillment of duties by all market participants; growth of stability of development of market subjects, increase of competitive advantages; ensuring the development of territories, including through the intensification of the decentralization process; ensuring protection of the interests of citizens, preserving the traditions, mentality of the nation. Such an approach will guarantee the national security of the state, society through increased macroeconomic stability, economic stability.

Keywords: national wealth; socio-economic development; ecological and economic priorities; globalization processes; natural wealth of the territory; national interests; ecosystems.

\section{Удк 330.52}

Вишневська О. М., доктор економічних наук, професор, декан обліково-фінансового факультету, Миколаївський національний аграрний університет, м. Миколаїв, Україна

Бобровська Н. В., кандидат економічних наук, старший викладач кафедри обліку і оподаткування, Миколаївський національний аграрний університет, м. Миколаїв, Україна

\section{Національне багатство держави: еколого-економічні критерії}

Анотація. У статті обгрунтовано сутність поняття «національне багатство» і узагальнено процеси $і$ явища, які здійснюють вплив на макроекономічне зростання держави з огляду на національне багатство, його кількісний склад і якісне наповнення. Обгрунтовано зростаючу потребу запровадження заходів з нівелювання негативного впливу глобалізаційних чинників на соціально-економічний розвиток держави, гарантування національної безпеки.

Ключові слова: національне багатство; соціально-економічний розвиток; еколого-економічні пріоритети; глобалізаційні процеси; природне багатство території; національні інтереси; екосистеми. 
Problem setting. The aggravation of socio-economic and ecolgical problems of mankind, the increasing influence of the global market on the national economies of the countries of the world, prompts the need to develop comprehensive approaches to guaranteeing national interests, including the preservation of the national wealth and its increase.

The national wealth is a collection of wealth created and accumulated in the work of the whole society, the level of education, production experience, the skill of creative potential of the population, taking into account historical processes and phenomena. The structure, quality and scale of national wealth determine the socioeconomic strength of the state, its potential and development opportunities in view of the created public goods, natural resources, nonmaterial wealth (educational, scientific, social and cultural, organizational potential).

Consequently, the national wealth is the consequence of a continuous process of accumulation and use of material and spiritual and intellectual results of labor, as well as the use of natural resources with the obtaining of certain benefits, mainly economic ones.

Analysis of recent researches and publications. At the theoretical and methodological level, the concept of "the national wealth" was studied by economists, among them: A. Anchyshkin, V. Bogachov, A. Weinstein, I. Gruzkov [1], A. Kalytnenko [3], L. Kvasha, V. Kirichenko, V. Popovkin [3], V. Rosynka [3], G. Sorokin, S. Strumilin, V. Savchuk, M. Khvesyk, S. Shumska[7]. The study of the national wealth in the context of economic development of the country is presented in scientific works: I. Bobuch [2], S. Doroguntsov, M. Kwak [8], S. Shumska [7]. Investigation of natural, human, intellectual, social capital as components of the national wealth of the state is investigated in the works of: T. Vlasova, O. Grishnova, le. Dragomirova, N. Zbagerska, M. Kostel, G. Lych, V. Nosik, A. Rubel, M. Shlapak. Most scholars note the importance of the national wealth of the state, the need for its preservation and multiplication.

The presence and effectiveness of the use of the national wealth are important basement for the development of the state economy, which determines the relevance of the research, as well as the theoretical significance and practical necessity in shaping the conditions for its preservation and multiplication.

Formulation of research objectives. Economic opportunities of the state can be estimated through the national wealth. As a result of increasing impact of globalization processes on the macroeconomic indicators of the state, there is a need for a quantitative and qualitative study of the system of the national wealth. An important feature of wealth is the use of economic resources necessary for the organization and support of human existence. Thus, the study of structural changes in the national wealth of the country becomes urgent because of the need to introduce priority directions of preservation of the resource base, ensuring the efficiency of use, which will promote the growth of macroeconomic stability.

The purpose of the study is to substantiate the essence of the concept of "the national wealth", the synthesis of processes and phenomena that have an impact on the macroeconomic stability of the state in view of national wealth, its quantitative composition and qualitative content. Particularly relevant issue is taking into account the growing need to level the negative impact of globalization factors on the socio-economic development of the world, the preservation of ecosystems.

The statement of basic results. The growth of the national wealth of the country is connected with the production of the national product and its reproduction, and also represents a set of material goods accumulated by society.

Consequently, the national wealth is all that the country and all the material wealth of a society possesses. Significant influence on the quantitative composition and quality filling is carried out by a historical factor whose action is continuous.

It is stated that the definition of the essence of the national wealth does not have the same views of scientists. I.V. Gruzkov notes that "under the most commonly widespread approach, under the national wealth we understand the value of the aggregate of the accumulated, created by nature and man resources and means of production, as well as the property of citizens belonging to the country or its residents, located in its territory and its borders, acts as a necessary condition for the production of goods, can be involved in economic turnover in order to meet the needs of the population at the present time of history "[1].

Bobuch I.M. believes that the national wealth is an important macroeconomic aggregate and capital stock of the nation, the result of the constantly reproducible process of using and saving human, natural resource, intangible and material elements to meet the needs of the nation and the development of the national economy.

Taking into account the priorities of the new paradigm of economic development, according to a two-staged research model, the national wealth is defined as the potential of socio-economic development of the country, which is a set of resources available in the state, which are the property rights of the state, legal entities and individuals - residents of the country that can be used to ensure the realization of the economic interests of individuals and legal entities for the purpose of social development, with the exception of outstanding external financial obligations [2].

It is revealed that as a measure of the general economic potential, the national wealth characterizes the general possibilities of the state or region, economic power, power, that is, first of all, the quantitative aspect of the functioning of the economy. The level of economic development and economic potential are interconnected 
as a combination of a quantitative and qualitative aspect of activity that characterizes the level of use of all productive resources, the ability to meet national and individual needs [3].
The mentioned national wealth of the state is investigated through macroeconomic indicators, spiritual and cultural values, natural wealth of the territory.

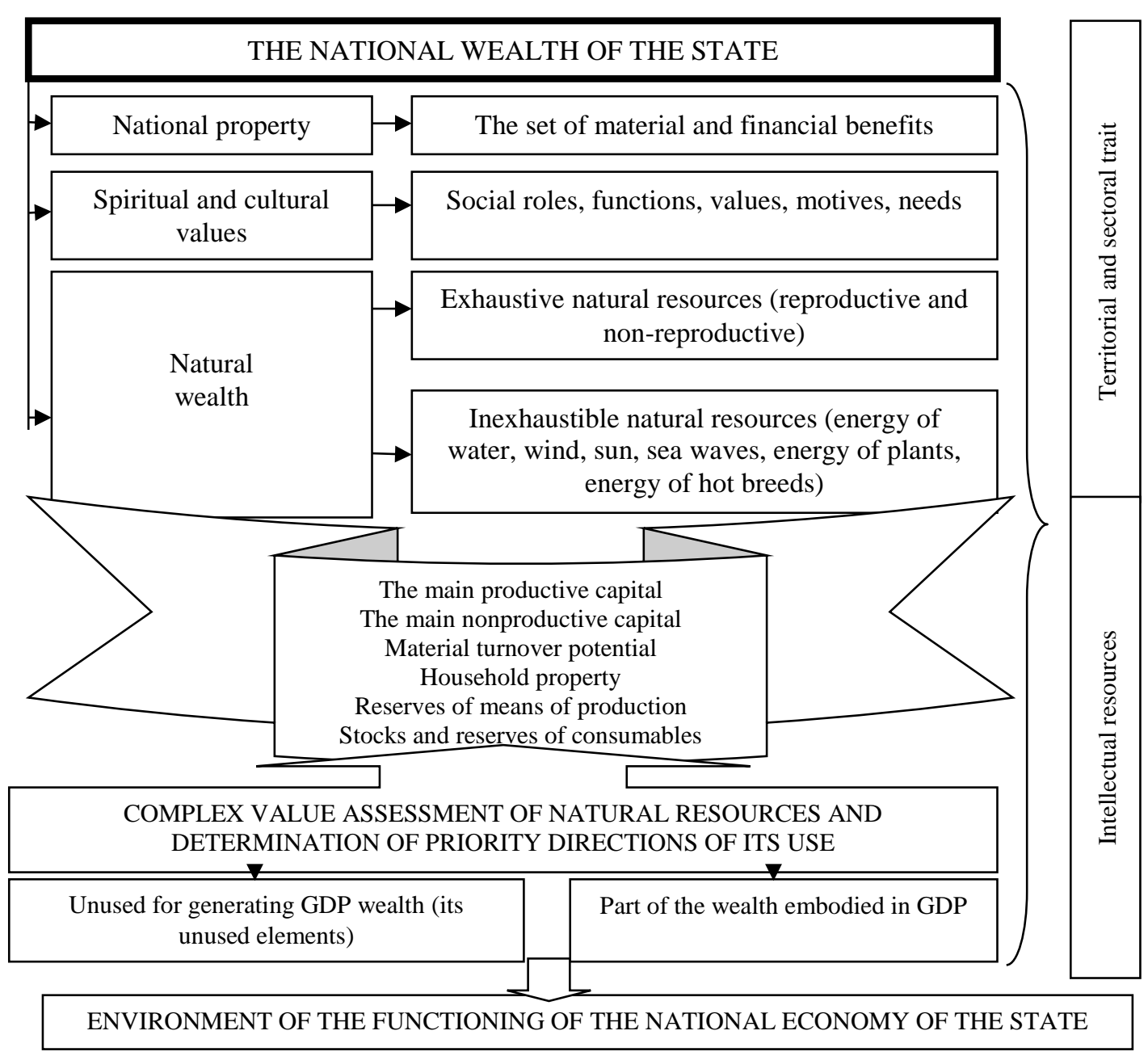

Figure 1 - Components of the national wealth of the state

Source: formed by authors

The analytical assessment of the distribution of the national wealth by component parts is necessary for a systematic study of macroeconomic indicators. The study of the accumulation of world resources, taking into account the territorial distribution of countries, allows us to determine the priority directions of economic activity of regions and opportunities for socio-economic development, including the influence of globalization, institutional transformations, innovation processes.
The growth of the share of national wealth of each country in the aggregate wealth characterizes the growth of the pace of the state development, its ability to make economic and political decisions. In this regard, the study of the national wealth of the state should have a systemic character, provide an information basis for the formation of an appropriate concept of state development, growth of its macroeconomic stability, protection of national interests, preservation of its integrity - territorially, culturally, mentally (fig. 2). 


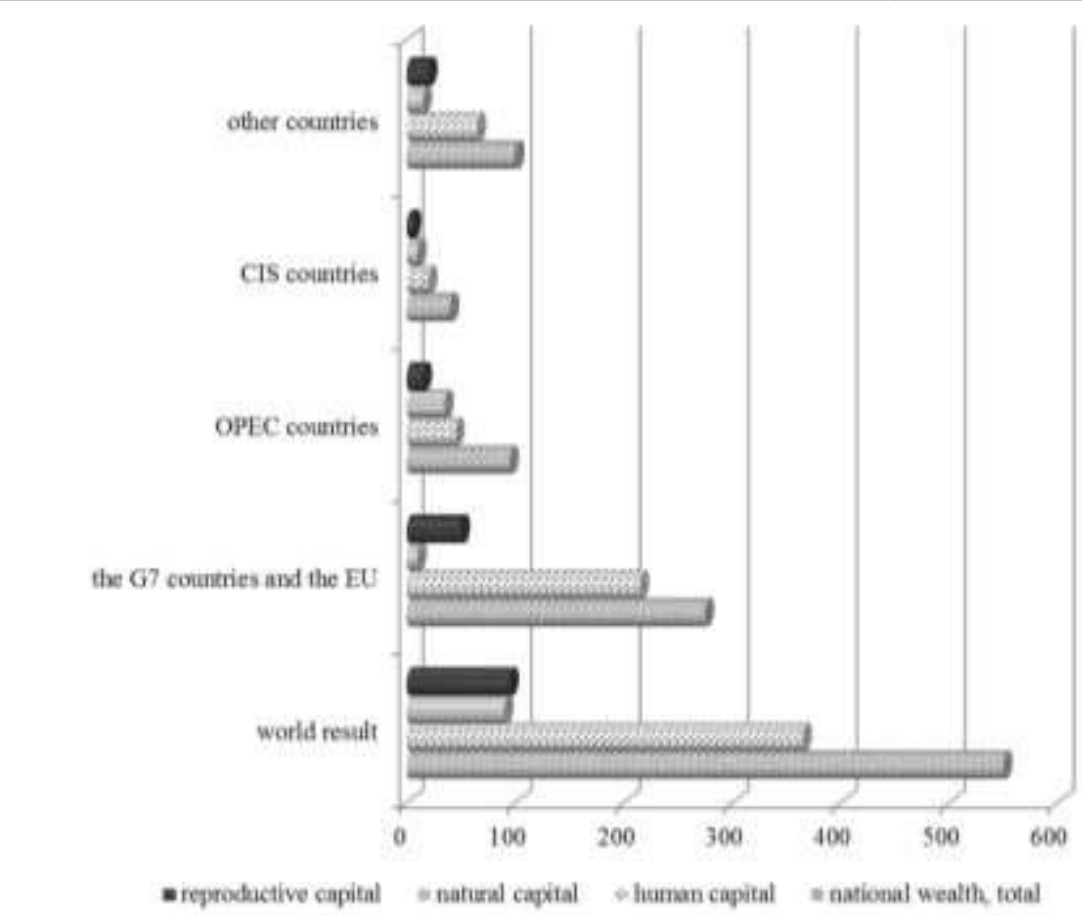

Figure 2 - The national wealth of the world by type of capital, trillion. dollars USA

Source: formed by authors using $[4,5,6]$

The study revealed that the concentration of the national wealth in the G-7 countries and the EU countries is most significant, which is due to the significantly stronger economic and political positions of countries in the global environment and in the global market. The CIS countries have a much lower level of aggregate national wealth, Ukraine is included in the aggregate of indicators.

The significance of national wealth is to create the preconditions for the next cycles of expanded reproduction of the economy. The increase of foreign economic dependence, the shadow economy, globalization processes in the reproduction of the national economy, lead to changes in the structure of the national wealth in the country. The unrestricted movement of all kinds of capital between states and the growth of foreign economic indebtedness can lead to the loss of the national wealth. The level of the national wealth per capita is analyzed (Fig. 3).

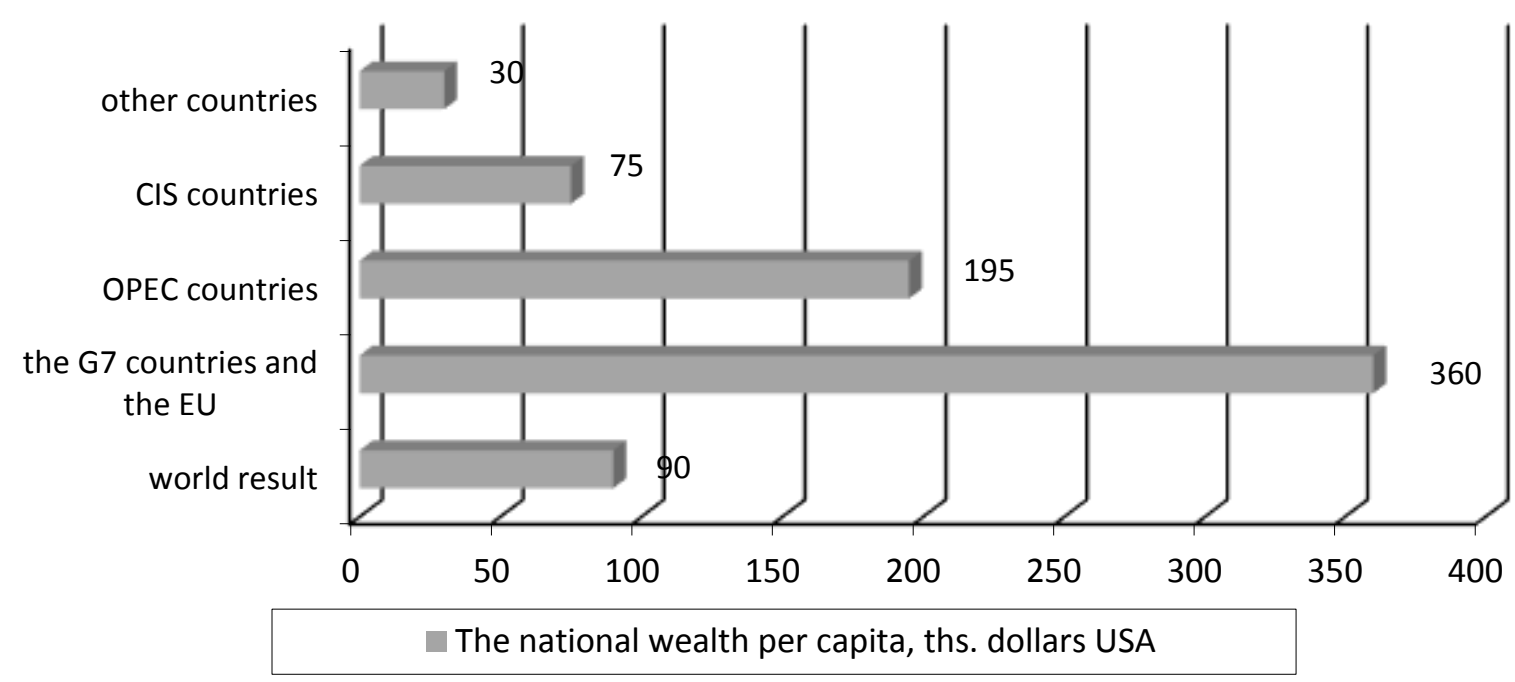

Figure 3 - National wealth of the world per capita, ths. dollars USA

Source: Formed by authors using $[4,5,6]$ 
It is estimated that the greatest concentration is the national wealth per capita in the G-7 countries and EU countries. An increase in the national wealth is usually equated with the growth of GDP and the population of the state. However, certain elements of wealth are spent on ensuring these changes, the part of GDP is consumed to meet the current needs of the nation, the part of it is aimed at creating future opportunities for reproduction of the national wealth, and the other part is for its increase. Thus, the national wealth, as a basis for macroeconomic categories, provides an opportunity to determine the potential competitive position of the state in the global environment, to assess the priorities in the formation and distribution of the national wealth at different levels of government.

State regulation of macroeconomic processes should provide for the effective use, preservation, accumulation and increase of the national wealth in order to solve the strategic tasks of socio-economic development, ecological sustainability of the state, which will strengthen the national competitiveness and ensure the level of national security. The policy of ecological development in the state should be based on the idea of a balanced reproduction of the national wealth.

We believe that the priority task of the society is to ensure the effective use, preservation and enhancement of all elements of the national wealth, adjusting the prospects for implementation of macroeconomic programmes for the long, medium and short-term periods, in accordance with the specificity, timeliness and the reality of implementation.

The role of state regulation is significant. That is why state regulation of macroeconomic processes in conjunction with state support in the use of the national wealth should be directed at the use of resource-saving technologies, rational nature management, in various fields of activity, which will enable to achieve the growth of competitive advantages of the state economy in the globalized environment.
Thus, through effective reproduction and multiplication of the national wealth, the state has the opportunity to strengthen its sovereignty, provide ecologically balanced and socio-economic development, guarantee national interests, both economic and ecological. Effectiveness of the state policy of using, saving and enhancing the national wealth depends on the effectiveness of the functioning of the national economy in the future, its competitive advantages in a globalized environment.

Conclusions. The national wealth of the state is a set of components that provide opportunities for the development of the economic sectors and the social sphere, support and guarantee national interests in view of the need to form a security environment, preserve the territorial integrity and mentality, the cultural heritage of the nation. The urgency of introducing measures to preserve the national wealth of the state is confirmed by the influence of globalization factors, the need to increase the competitive position in the global market.

It is stipulated that state policy should be aimed at systematic implementation of actions complex that guarantee the national interests, preserve, increase the national wealth, and provide a safe economic and ecological space. The practical implementation of measures is to comply with social and ecological responsibility, fulfillment of obligations by all market participants; stability growth of market subjects development, increase of competitive advantages; ensuring the development of territories, through the intensification of the decentralization process; ensuring protection of the citizens interests, preserving the traditions, mentality of the nation. Such an approach will guarantee the national security of the state, society through increased macroeconomic stability, economic stability.

\section{Література:}

1. Грузков И. В. Человеческий капитал в структуре национального богатства / И. В. Грузков // Вестник Северо Кавказского государственного технического университета. - 2009. - № 2 (19). - С. 112-117.

2. Бобух I. М. Пропорції та перспективи формування національного багатства України [Текст] : монографія / I. М. Бобух ; НАН України ; Ін-т екон. та прогнозув. - К., 2010. - 372 с.; с. 30.

3. Поповкін В. А. Рівні соціально-економічного розвитку регіонів України / В. А. Поповкін, А. П. Калитенко, В. О. Розинка // Наукові доповіді. Випуск 24. - Київ:НІСД, 1994.

4. Стратегія економічного і соціального розвитку України (2004-2015 роки) «Шляхом Європейської інтеграції» / Авт. кол. : А. С. Гальчинський, В.М. Геєць та ін.; нац. Ін.-т стратег дослідж., Ін.-т екон. Прогнозування НАН України, М-во економіки та 3 питань європ. Інтегр. України.-К.: ІВЦ Держкомстату України, 2004-416 с.

5. Стратегія інноваційного розвитку України на 2010-2020 роки в умовах глобалізаційних викликів (проект) // Офіційний сайт Верховної Ради України (Комітет з питань освти і науки) // [Електронний ресурс] / Режим доступу: http://kno.rada.gov.ua/komosviti/control/uk/publish/article?art_id=47920\&cat_id=46017\&sho wHidden=1.

6. Стратегія розвитку України «Україна 2020: стратегія національної модернізації» // [Електронний ресурс] / Режим доступу: http://www.radakmu.org.ua /uk/news_and_report/1079.html.

7. Шумська С. С. Національне багатство: методологічні підходи та оцінки по Україні / С. С. Шумська // Економічна теорія. - 2006. - № 4. - С. 62-76. 
Електронне наукове фахове видання з економічних наук "Modern Economics», №10 (2018), 23-28

(1) https://modecon.mnau.edu.ua | ISSN 2521-6392

8. Квак М. Національне багатство України: стан та перспективи / М. Квак // Економіка управління національним господарством. - Вісник ТНЕУ. - № 1. - 2008. - С. 29-36.

\section{References:}

1. Gruzkov, I. V. (2009). Human capital in the structure of national wealth. Vestnik Severo Kavkazskogo gosudarstvennogo tekhnicheskogo universiteta, vol. 2 (19). pp. 112-117.

2. Bobuh, I.M. (2010). Proporciyi ta perspekty `vy formuvannya nacional 'nogo bagatstva Ukrayiny` [Proportions and prospects of formation of national wealth of Ukraine], National Academy of Sciences of Ukraine; Institute of economy. and predicting, Kyiv, Ukraine.

3. Popovkin, V. A. (1994). Levels of Socio-Economic Development of the Regions of Ukraine. Naukovi dopovidi, iss. 24, Kyiv: NISS.

4. Galchinskyi, A. S. and Geyets, V. M. (2004). Strategy of Economic and Social Development of Ukraine (2004-2015) "By the Way of European Integration", National Institute for Strategic Studies, Institute of Economic Forecasting of the National Academy of Sciences of Ukraine, Ministry of Economics and European Affairs, Ukraine, Kyiv, IEC of the State Statistics Committee of Ukraine.

5. The Verkhovna Rada of Ukraine, The Strategy of Innovative Development of Ukraine for 2010-2020 in the context of globalization challenges (project), available at: http://kno.rada.gov .ua / komosviti / control / uk / publish / article? art_id = 47920 \& cat_id $=46017$ \& sho wHidden $=1$ (Accessed 01 July 2018).

6. Development Strategy of Ukraine "Ukraine 2020: A Strategy for National Modernization", available at: http://www.radakmu.org.ua/uk/news_and_report/1079.html (Accessed 01 July 2018).

7. Shumska, S. S. (2006). The national wealth: methodological approaches and assessments in Ukraine, Economic Theory, vol.4, pp. $62-76$.

8. Kvak, M. (2008). The national wealth of Ukraine: state and prospects. Ekonomika upravlinnya nacionalnym gospodarstvom, Visny`k TNEU, vol.1, pp. 29-36.

Ця робота ліцензована Creative Commons Attribution 4.0 International License 